\title{
Students of Color and Public Montessori Schools: A Review of the Literature
}

\author{
Mira C. Debs ${ }^{1}$ and Katie E. Brown $\dagger^{2}$ \\ ${ }^{1}$ Yale University \\ ${ }^{2}$ National Center for Montessori in the Public Sector
}

\section{Acknowledgments}

Thank you to Kellie Meyers, whose request for data inspired this article, and to the editor and anonymous reviewers of the Journal of Montessori Research for their comments. Please note the following author affiliations: Katie Brown oversees the Montessori Teacher Residency, and both Brown and Mira Debs are involved with Montessori for Social Justice.

Keywords: minority, students of color, Montessori, urban education, school choice

\begin{abstract}
Students of color comprise a majority in public Montessori school enrollments around the United States, and practitioners are often asked for evidence of the Montessori Method's benefits for these students. This article examines the relevant literature related to the experiences of students of color in public Montessori schools. Research finds Montessori education offers both opportunities and limitations for students of color in attending diverse schools, developing executive functions, achieving academically, accessing early childhood education and culturally responsive education, minimizing racially disproportionate discipline, and limiting overidentification for special education. Public Montessori education's efficacy with students of color may be limited by several factors: the lack of diversity of the teaching staff and culturally responsive teacher education, schools that struggle to maintain racially diverse enrollments, and the challenge of communicating Montessori's benefits to families with alternative views of education. The review concludes with directions for future research.
\end{abstract}

\section{Students of Color and Public Montessori Schools: A Review of the Literature}

One of the foremost priorities of American public education-reform efforts has been to eliminate the opportunity gap for students of color, particularly in urban schools. While the term achievement gap has long been used to describe the disparity in academic outcomes between White, middle-class students and low-income students of color, scholars like Gloria Ladson-Billings (2013) have argued that this phenomenon should be reframed as a disparity in opportunities to learn. Researchers have long debated the primary causes of this gap, including disproportionate poverty and childhood trauma for some students of color, underfunding of public education, continuation of segregated schools, shortage of quality teachers, racially biased tests, and other legacies of racism ( $\mathrm{Au}, 2010$; Anyon, 2014; Darling-Hammond, 2010; Ladson-Billings \& Tate, 1995). One model for many urban charter schools has been to set up longer school days and school years alongside a strict system of rewards and punishments - in essence, a more concentrated dose of traditional school (Carter, 2000; Thernstrom \& Thernstrom, 2004). These urban charter schools were initially hailed for their academic results, but today they face increasing scrutiny for 
disciplinary practices that have resulted in higher levels of student suspensions and expulsions than found in neighboring district schools. In addition, while graduates of these high-performing charter schools have college persistence rates that are higher than the average rates for Black and Latino students, they are still far lower than White and Asian graduation rates, suggesting that these students are still not receiving critical skills for college readiness (Golann, 2015; Goodman, 2013). More broadly, scholars have repeatedly questioned whether the traditional factory model of education best serves students' needs, particularly those students of color (Hall, 2006; Hall \& Murray, 2011; Kunjufu, 2005; Ladson-Billings, 1994; Noguera, 2003).

Montessori public schools offer a distinct contrast to methods used by traditional public schools, including these high-performing, strict-discipline charter schools. There, the teacher is the authority, children remain at their desks, and learning is highly regimented and standardized. In contrast, children in public Montessori schools work at their own pace on sequential lessons, and their learning is individually tailored. They collaborate with other students, moving freely around the classroom, and the curriculum emphasizes community building as students develop strong relationships with the same teacher over 3 years. In consideration of these significant differences, our study examines existing research to answer the question: How effectively do public Montessori schools serve students of color?

In the last 40 years, public Montessori schools have expanded exponentially to over 500 schools that serve approximately 125,000 students, forming the largest alternative pedagogy in the U.S. public school system (National Center for Montessori in the Public Sector [NCMPS], 2014). In a survey of 300 of these public Montessori schools in 2012-2013, 54\% of students were students of color, comprising Black, Latino, Asian, Native American, Pacific Islander, and multiracial students (Debs, 2016b). Black students were enrolled in public Montessori schools at a rate that is $11 \%$ higher than the nationwide rate for public schools. Moreover, public Montessori school students, and Black and Latino students in particular, were more likely to attend a racially diverse school (between $25 \%$ and $75 \%$ students of color) compared to students nationwide (Debs, 2016b).

In light of this racial diversity, we evaluate existing research on the efficacy and limitations of public Montessori education for students of color and important gaps in the research. In particular, we update and expand research by Hall and Murray (2011) that examined Black students and the potential intersections of Montessori practice and culturally responsive pedagogy, an approach that promotes students' cultural strengths to support their well-being and achievement. We find that public Montessori education demonstrates strengths in racial diversity, mixed results in student outcomes, and promising potential in early childhood, special education, and cultural responsiveness. We recognize that Montessori schools are not a panacea to the broader set of social disadvantages that students of color face. Ultimately, though, we argue that further research into the experiences of students of color in Montessori schools will give educators and policymakers the tools to more effectively identify Montessori's strengths in these areas and to better identify areas of improvement. We conclude with next steps for both practitioners and policymakers.

\section{Public Montessori Education and Racial Diversity}

The Montessori Method has its roots in serving disadvantaged students. Montessori education began over a century ago by serving the poorest urban children in Rome, Italy. Similarly, in the United States, public Montessori schools have a 50-year history of creating racially and socioeconomically diverse schools. To support poor children, American public educators began to bring the Montessori Method to schools and classrooms to provide quality early childhood education via Head Start in the late 1960s. Subsequently, educators used Montessori education as a means to desegregate urban school districts including Cincinnati, Ohio; Kansas City, Missouri; and Milwaukee, Wisconsin. More recently, cities such as Cambridge, Massachusetts; Hartford, Connecticut; and Fort Wayne, Indiana, have successfully used Montessori education to retain families in urban district schools (NCMPS, 2014).

Today, in a landscape of increasing school segregation around the United States (Orfield, Kucsera, \& Siegel-Hawley, 2012), public Montessori schools remain racially diverse (Debs, 2016b). This racial 
diversity is important because research has consistently shown that students attending racially diverse schools have higher achievement in mathematics (Berends \& Penaloza, 2010; Newton, 2010) and literacy (Benson \& Borman, 2010) and build more expansive social networks (Braddock \& Gonzalez, 2010; Goldsmith, 2010; Wells, Holme, Revilla, \& Atanda, 2009). Of the roughly 500 public Montessori schools, 300 are schoolwide programs with available data on the racial, ethnic, and socioeconomic composition of their student body. Half of the 300 schoolwide, public Montessori programs enroll a racially diverse student body (between $25 \%$ and $75 \%$ students of color). In 23\% of these schools, a majority (75\%-100\%) of enrolled students are students of color (Debs, 2016b). Half of these 300 schoolwide programs are located in urban areas (Debs, 2016b). We have less information about the 203 Montessori programs that are located within traditional schools, but some initial evidence (e.g., a study of student demographics in South Carolina's robust public Montessori sector) demonstrates that these partial school programs enroll a racially and economically diverse student population as well (Furman University, 2015). Thus, a clear and enduring strength of public Montessori programs has been their success in enrolling a racially diverse student body in schools around the country.

Although public Montessori schools are distinguished by their racial diversity, by other measures, many schools have Whiter or wealthier student enrollments than those in their surrounding districts. Over two thirds of schoolwide public Montessori schools enroll fewer students of color than their surrounding districts do (Debs, 2016b); this difference is even more pronounced in Montessori charter schools (Brown, 2016a). Roberts and Fleming (2016) found a similar enrollment pattern in South Carolina's public Montessori programs within schools. Enrolling a higher proportion of White students can be positive if the resulting Montessori school is racially diverse in an overwhelmingly monoracial district, but it may be a problem if the public Montessori enrollment is significantly different from that of the surrounding district. In several cases in Washington, California, Oregon, and Wisconsin, public Montessori charter applications have been denied, charter renewals have been given extra scrutiny, and programs have been closed because of concerns about disproportionately White enrollments ("EGUSD staff,” 2016; McCord, 2012; Nyland, 2015; Swedien, 2013; Wong, 2014).

Maintaining student diversity in public Montessori schools requires constant vigilance from school administrators and policy makers, as structural and cultural factors can impede the enrollment of students of color. Most public Montessori schools are a component of choice programs, including choices within schools, selective magnets, and charters. To enroll their children, parents must research their choices, navigate complicated information systems, and sometimes provide transportation, all of which are significant burdens for the poorest families. One great strength of public Montessori education is that students often begin these programs at age 3 or 4, but limited public funding causes some schools to charge tuition for preschool programming, thereby restricting the diversity of students who can attend the school. Further, a number of public Montessori schools that began with missions to attract a racially diverse student body have found their enrollments becoming increasingly White (Makris \& Brown, in press). Several charters, like Baltimore Montessori Charter in Maryland and City Garden Montessori School in St. Louis, Missouri, are now exploring the use of a weighted lottery to maintain racial balance at their schools (Bowie, 2016; Prothero, 2016). Research thus far shows that public Montessori schools are particularly strong in creating racially diverse student enrollments, but maintaining such diversity requires intentional efforts to reduce barriers and increase access.

\section{Montessori Students of Color and Academic Achievement}

While research has identified the diversity strengths of public Montessori education, research on outcomes for Montessori students of color has been inconclusive and limited in both size and scope. One complicating factor for the development of large studies across public Montessori schools is that Montessori implementation varies widely in the public sector (Murray \& Peyton, 2008), and these variations have been shown to have an impact on student outcomes (Lillard, 2012). In recent years, policymakers and researchers have therefore been working to define high-quality Montessori to include, at minimum, the following elements: Montessori-trained teachers and administrators, a majority of Montessori materials, students 
working in 3-hour cycles, and multiage classrooms that span three grade levels (NCMPS, 2016a).

Some initial findings suggest that public Montessori programs can benefit Black and Latino students. A recent study found that Black third graders in a public Montessori magnet school outperformed their traditional school counterparts in both reading and math. When compared to other magnet students in the same district, these Black Montessori students still performed better in reading and equally in math (Brown, 2016b). Dohrmann, Nishida, Gartner, Lipsky, and Grimm (2007) found that a racially diverse group of pre-K through fifth-grade students who attended a high-quality public Montessori program (i.e., one with Montessori-trained teachers; Montessori materials; multiage classrooms; and long, independent work blocks) had a pronounced advantage in high school math and science, even 7 years after leaving the Montessori program. These students had higher scores on standardized tests of math and science and higher subject-specific grade point averages in high school than their non-Montessori peers. In the largest cohort study to date, Ansari and Winsler (2014) examined 709 low-income Black and Latino 4-year-olds and found strong developmental gains for Latino students following only 1 year of Montessori pre-K in Miami-Dade County Public Schools, with more modest gains seen among Black students. Despite the sample size, two factors limited the Ansari and Winsler (2014) study: the public Montessori programs in Miami included only 4-year-olds (i.e., not children in multiage classrooms), and the study evaluated only 1 year of implementation. Another study of a bilingual Montessori preschool program (Rodriguez, Irby, Brown, LaraAlecio, \& Galloway, 2005) found that Latino Montessori students made greater gains in both English and Spanish language acquisition than did their peers in a traditional bilingual program. Not all findings have been positive, however. Using a majority-minority student sample, Lopata, Wallace, and Finn (2005) found no clear advantage on standardized math and language arts assessments for fourth- and eighth-grade Montessori students as compared to their peers in traditional and magnet schools.

While a number of studies have featured racially and socioeconomically diverse public Montessori student samples, researchers frequently have not disaggregated data by race, making it difficult to evaluate academic and noncognitive outcomes for students of color (Dohrmann et al., 2007; Duax, 1989; Ervin, Wash, \& Mecca, 2010; Lillard \& Else-Quest, 2006; Lopata et al., 2005; Mallett \& Schroeder, 2015; Moody \& Riga, 2011). Public Montessori leaders around the country have reported strong academic gains and high graduation rates for students of color in their programs (East Dallas Community Schools, 2010; Moody \& Riga, 2011), but the widespread racial achievement gaps in American public education have also been found in public Montessori schools (Mallett, 2014). To better understand the performance of students of color in public Montessori schools, it is critical that future research projects disaggregate students by racial and ethnic background, as well as by income level and English-language learner and special education status.

Further, existing research on public Montessori education has been limited in studying students of color, in part because of the small sample sizes in the studies (Lillard \& Else-Quest, 2006), the short duration of the research (Ansari \& Winsler, 2014), and the difficulty of measuring whether families who choose Montessori are different from nonchoosers. Thus, two research gaps in public Montessori education are noted: (a) national studies that focus on the achievement of students of color and (b) longitudinal studies that compare families that choose Montessori education with families that do not.

Other Montessori studies have focused on gains in noncognitive skills related to academic achievement and professional success. Montessori has been shown to be particularly effective for all students in fostering the development of executive functions like self-discipline, critical reasoning, and problem-solving (Diamond \& Lee, 2011; Ervin et al., 2010; Lillard, 2005, 2012; Lillard \& Else-Quest, 2006; Rathunde \& Csikszentmihalyi, 2005). These executive functions help students self-regulate as their learning becomes more independent in college and in the workplace (Mischel, Shoda, \& Rodriguez, 1989; Mischel et al., 2011; Tough, 2012). Executive functions also help empower students to be agents of change in their communities. In particular, Lillard and Else-Quest (2006) found a strong sense of school community and a willingness to be proactive in resolving peer conflict among Milwaukee public Montessori middle school students. Further research is needed on the noncognitive effects of Montessori education on students of color. 


\section{Montessori and Early Childhood Education for Students of Color}

Because Montessori programs ideally begin with children at age 3, they provide a significant opportunity to build strong foundations for academic achievement among students of color. The work of economist James Heckman suggests that public investments in early childhood education pay dividends for many years, especially for economically disadvantaged students (Heckman, 2012). This investment is particularly important for Black and Latino children, who attend preschool at lower rates than their White peers (U.S. Department of Education, 2015). As an early childhood program that promotes school readiness, academic development, and noncognitive skills, the Montessori Method meets Heckman's criteria for highquality early learning. Moreover, by emphasizing playful learning (Lillard, 2013), Montessori education occupies the middle ground between entirely play-based and entirely academics-based preschool (Lillard et al., 2013). Montessori education also represents a model that can sustain students from early childhood through elementary school and beyond.

As Black preschoolers are in the racial group most likely to attend low-quality preschools (U.S. Department of Education, 2015), expanding access to public Montessori pre-K constitutes an opportunity to significantly improve early learning experiences for these students. More research is needed to demonstrate the advantages of these programs for students of color. The Ansari and Winsler study (2014) of Black and Latino 4-year-olds found strong improvement in Latino students in the areas of pre-academic and behavioral skills after 1 year of public Montessori preschool; gains for Black students were comparable to those seen in traditional preschool programs. Similar study designs in fully implemented Montessori programs would be useful to determine if these results were consistent at other sites and after the full 3year primary cycle.

\section{Racially Disproportionate Discipline}

Just as Montessori preschool may provide a strong educational beginning for students of color, Montessori education may also help to reduce the overuse of exclusionary discipline (e.g., suspension and expulsion) for students of color (Skiba, Michael, Nardo, \& Peterson, 2002). Students of color are two to three times more likely to be suspended or expelled from school than their White peers, even for the same offenses (Skiba et al., 2002). This racially disproportionate discipline is partially attributable to the spread of zero-tolerance policies and school cultures that emphasize uniformity and compliance, as well as to a shortage of culturally sensitive teachers (Irvine, 1990; Shedd, 2015). The Montessori approach, with its emphasis on positive behavioral interventions, personalized learning, and following the child, both combats overreaching disciplinary practices and encourages teachers to learn about the unique cultural heritage of each student. The Montessori curricula of Grace and Courtesy and Peace may also contribute to lower levels of disciplinary sanctions by fostering conflict resolution and teaching social interaction skills that build mutual respect. Montessori students enjoy the freedom to move around and work together, practices that align closely with students of color who may come from communal and collaborative home cultures (Hall, 2006).

Initial research into public Montessori education and discipline has yielded some important findings. Brown and Steele (2015) examined racial discipline disproportionality for Black students in Montessori schools and in comparable traditional public schools in a large, urban district in the Southeast. While Black students were still suspended at disproportionately higher rates compared to White students in public Montessori elementary schools, this disproportionality was far less severe than in the traditional schools. These findings are significant, albeit preliminary, and further empirical research is needed to examine how Montessori may disrupt racialized exclusionary discipline practices.

\section{Special Education}

Another area in which Montessori research could demonstrate particular benefits for students of color is in their overrepresentation in special education (Lewis, Chambers, \& Butler, 2012). While students with learning differences in traditional public education must qualify for an individualized education plan, 
all Montessori students enjoy a curriculum designed for their own needs and pace, allowing for differentiated instruction in the classroom. Because classrooms are multiage, students are less likely to feel the stigma of their learning differences in relation to their peers. Curriculum individualization can also reduce special education referrals, which may indirectly remedy this overrepresentation (García \& Ortiz, 2006; Green, 2005). Cossentino (2010) noted the natural overlap between the Montessori Method and the inclusion model of education for students with learning disabilities. For the many Black and Latino students who are eligible for special education, an inclusion model may mitigate the "racial isolation resulting from segregation based on disability" (Connor \& Ferri, 2007, p. 69). Research on Montessori and special education is in the early stages, but Danner (2015) found Montessori-specific practices like peer support and multiage classrooms particularly conducive to full inclusion of special education students. But while Montessori teachers were enthusiastic about inclusion of special needs students, they received less training in inclusion than did their traditional school counterparts (Danner \& Fowler, 2015). Additional research in this area may help determine the educational impact of a Montessori classroom on students with special needs.

\section{Montessori and Cultural Responsiveness}

Montessori teachers also pay close attention to children's cultural context, and a growing body of qualitative research focuses on Montessori as a culturally responsive teaching approach. Culturally responsive teaching acknowledges that teachers should incorporate students' home cultures into their lessons (Ladson-Billings, 1995). Many researchers argue that cultural responsiveness can improve educational outcomes for students of color by affirming, rather than marginalizing, key aspects of children's identities (Gay, 2010; Ladson-Billings, 1995).

Similarly, Montessori education allows children to bring into the classroom their own cultural funds of knowledge - the cultural skills and knowledge students bring with them from their families and communities (Moll, Amanti, Neff, \& Gonzalez, 1992). Dr. Montessori's son Mario Montessori, who developed much of the Montessori elementary curriculum, described schools as a "cultural environment" where students should "become familiar with basic aspects of their own culture ... [and] enlarge their cultural horizon” (Montessori, 1976, p. 42). This description suggests that a focus on a child's unique cultural background is, or should be, an inherent element of the Montessori Method.

A number of schools serving indigenous students in the United States employ the Montessori Method as a vehicle to pass on linguistic and cultural traditions. Schonleber (2011) documented the integration of the Montessori approach in Hawaiian language and culture-based immersion programs. A number of Native American Montessori programs align with cultural preservation efforts on reservations around the country (Ayer, 2016a; "Fort Peck combines language," 1998; "Head Start turns 50," 2015; Hixon, 2002; Johnson, 2005; Johnston, 2016). A small but significant cohort of Montessori teachers of color work in public and private Montessori schools, often combining the Montessori Method with cultural pride and social-justice teaching (Alston, 2008; Trondson, 2016).

Others have argued that celebrating a student's cultural background is not enough. Culturally sustaining pedagogy describes the practice of not only incorporating cultural pluralism but also teaching students how to be advocates for equality (Paris \& Alim, 2014; Paris \& Winn, 2013). Another related practice is antibias, antiracist (ABAR) education. Some early research is examining efforts to implement ABAR practices in public Montessori schools (Banks \& Maixner, 2016). Where culturally responsive practices support the unique cultural background of each child, ABAR education helps teachers develop awareness of their own implicit biases and the social structures that grant privilege to some individuals, and ABAR education encourages teachers to create change in their classrooms and schools (Pollock, 2008). Further research could document ABAR practices in public Montessori schools and examine their effects on students, families, and teachers.

Bilingual Montessori programs can also support English-language learners and affirm students' home cultures (Rodriguez et al., 2005). The multiage structure of Montessori classrooms means that 
children typically stay with the same teacher for 3 years, which helps teachers develop a deep knowledge of their students and may lead to strong working relationships with their families. Studies of looping-the practice in which teachers stay with their students for multiple, consecutive years-support this conclusion (Thompson, Franz, \& Miller, 2009). Several case studies have documented promising applications of the Montessori Method as a culturally sustaining practice; additional research is needed to explore the benefits of this work.

While the Montessori Method lends itself to cultural responsiveness, a perceived lack of such may dissuade families of color from enrolling in public Montessori programs. Montessori's focus on the individual child may encourage teachers to be colorblind (Lewis, 2001), overlooking the critical roles of class, race, and culture in students' identities. Some practices and assumptions must be presented to families of color with context and care to avoid further alienating them; examples may include focusing on abstract ideas of education instead of concrete learning outcomes or advising parents to bring Montessori into the home (Debs, 2016a). Montessori schools and teachers can strengthen their work with diverse student populations through continued conversations about race and other forms of bias and through training and professional development in culturally responsive education models (Banks \& Maixner, 2016).

Additional limitations to practicing culturally responsive Montessori education are the marginal nature of this topic within Montessori teacher preparation and the shortage of Montessori teachers of color. While the standards for Montessori teacher preparation programs established by the Montessori Accreditation Council for Teacher Education ([MACTE], 2016) include criteria for culturally responsive education, it is unclear how effectively or consistently Montessori teacher preparation programs incorporate them.

Similar to the nationwide public school teacher pool, which is over three quarters White and over 80\% female (U.S. Department of Education, 2013), public Montessori teachers are also disproportionately White and female. None of the three Montessori organizations that oversee the majority of American Montessori teacher preparation centers (i.e., Association Montessori Internationale, American Montessori Society, and MACTE) collect data on the racial or ethnic diversity of their teacher trainees or their broader membership (B. Beste, personal communication, December 9, 2015; C. Hofland, personal communication, December 7, 2015; R. Pelton, personal communication, March 26, 2016). A 2016 NCMPS initial survey of 311 teacher trainees found that $69 \%$ of respondents were White and 90\% were female (NCMPS, 2016b), likely a more diverse enrollment than in previous years but still predominantly White and female.

This clear majority of White teachers is significant because education researchers argue that White teachers may have lower expectations for their students of color than teachers of color do (Gershenson, Holt, \& Papageorge, 2016). Like their traditional public school counterparts, public Montessori teachers may also exhibit cultural biases when working with students of color (Stansbury, 2012; Yezbick, 2007). Some Montessori teachers of color also reported feeling isolated and marginalized in the profession, with few opportunities for honest conversations about race (Trondson, 2016). The Montessori teacher pool can become more diverse through efforts like outreach and increased funding for Montessori training for teachers of color. Future research may help develop best practices for culturally responsive education in Montessori classrooms and recruiting Montessori teachers of color.

In addition, Montessori teacher preparation programs have traditionally focused on preparing teachers for private schools that still dominate the American Montessori landscape (Whitescarver \& Cossentino, 2008). The concern with Montessori fidelity sometimes makes Montessori teachers reluctant to incorporate new approaches that support struggling students. Moreover, public Montessori teachers need ongoing support and training to integrate the demands of the Montessori curriculum with state and national standards like the Common Core (Van Acker, 2013). Given the sustained growth of Montessori in the public sector, Montessori teacher preparation programs and public school districts should consider collaborating to design training for teachers who will work with racially and socioeconomically diverse students. The DC Montessori Teacher Residency program, currently in the pilot phase in Washington, DC ("DC Montessori Residency,” n.d.), is one example of such a program. The Residency augments high-quality Montessori teacher preparation with professional development and training to prepare teachers for service in high-need 
public schools. Residents receive supplemental instruction in cultural competency, family engagement, and support for English-language learners. This program is one example of a model that combines Montessori preparation with additional training for a public school context.

The Montessori Method is already deployed as a culturally responsive model in a number of schools serving indigenous students. Teacher preparation in this area and research into best practices may help Montessori teachers develop culturally responsive and ABAR practices in their classrooms. Moreover, evidence of the importance of teachers of color and of racial bias in Montessori classrooms indicates the significance of sustained efforts to recruit a more diverse Montessori teaching force, particularly in public Montessori schools.

\section{Conclusion and Future Directions}

Research indicates that the Montessori Method in public schools offers both opportunities and limitations for students of color. In this section, we summarize our findings and make policy recommendations for educators. Public Montessori schools attract a majority of students of color, and Black and Latino public Montessori students are more likely to attend racially diverse schools than are their traditional public school counterparts. Central to Montessori education are individual autonomy, respectincluding respect for students' cultural backgrounds—and positive discipline. Students with special needs may integrate particularly well in multiage classrooms, where all students have individualized learning programs.

At the same time, research suggests that students of color face obstacles in enrolling in public and private Montessori schools. While tuition is the greatest obstacle to private Montessori schools, parents also face enrollment challenges in public Montessori schools, including informational and logistical barriers related to school choice. The results of these challenges are evident in charter schools, whose enrollments feature a lower percentage of students of color in comparison to both Montessori magnets and the charters' surrounding districts (Debs, 2016a). Public Montessori schools should work to eliminate enrollment barriers through district lotteries, strategic recruitment in low-income communities and communities of color, free transportation and lunch, before- and after-school care, and sliding scales for preschool tuition. ${ }^{1}$ Private Montessori schools also can prioritize a racially and economically diverse enrollment as part of their school mission and can raise funds to do so. A small but growing number of "intentionally diverse" (Wohlstetter, 2016) private Montessori schools offer sliding-scale tuitions. Some of these schools have a goal of an enrollment comprising 50\% low-income students, becoming a public-private hybrid of "tuitionbased, access-oriented” schools (Ayer, 2016b, para. 3).

Debs (2016b) cautioned Montessori educators against using terms like good fit or bad fit to influence parents' school choices. Families' racial, ethnic, and social backgrounds influence their educational experiences and the questions they may have about Montessori education. Parents of color may be reluctant to choose Montessori schools due to perceptions that they do not deliver an academically rigorous and culturally responsive education. Therefore, Montessori educators should speak explicitly about academic achievement, rather than downplay it, so parents know that Montessori is a college-preparatory curriculum.

Once Montessori schools increase the enrollment of students of color, they need to demonstrate that students of color succeed in their schools. The Montessori research community should explicitly examine both academic and nonacademic outcomes for students of color and then share their findings, both positive and negative, with the broader education community via peer-reviewed journals. This research requires an explicit disaggregation of data and a commitment to focus on the particular experiences of students of color, in contrast to previous research that has avoided discussions of race entirely. Just as the charter sector as a whole is subject to rigorous national study, public Montessori schools would benefit from

\footnotetext{
${ }^{1}$ For a complete list of equitable enrollment strategies and measures to include cultural responsiveness in the Montessori classroom, see Debs (2016a.)
} 
national-level studies that examine student outcomes and additional qualitative research that identifies best practices. The Furman University study in South Carolina is an important step toward this goal, but more research on the outcomes for students of color is urgently needed. It is also important that educators honestly reflect on Montessori practices to determine which practices are successful and which should be supplemented to effectively serve all students; this reflection also will guide the development of school strategies that ensure inclusive academic success. Making progress in this area is the Montessori for Equity Collaborative, a coalition of public school leaders who share best practices for academic equity via monthly conference calls (Fabel, 2016).

To support the needs of students and families of color, Montessori educators should become leaders in developing culturally responsive and ABAR practices. Private and public schools-like Chicago's private Near North Montessori School and City Garden Montessori School, a public charter school in St. Louis-have implemented schoolwide diversity and antiracism training for their staff. Important, early efforts toward this goal include ABAR training at the Montessori for Social Justice 2016 conference, the AMI/USA 2017 Refresher Course, and public and private Montessori schools around the country. These actions are vital in developing both a common antiracism language and strategies for Montessori teachers to address the broader social problems that influence their classrooms and help break cycles of racism and bias.

Finally, it is incumbent upon Montessori training centers to make a concerted effort to diversify their teaching corps. To raise the national profile of Montessori teacher preparation, NCMPS created Teach Montessori, a web portal that connects candidates to relevant training centers (Teach Montessori, 2017). As of 2016, Teach Montessori staff members were actively recruiting Montessori trainees at college job fairs around the Northeastern United States, instead of using traditionally passive, word-of-mouth enrollment practices. The DC Montessori Teacher Residency also aims to add more Montessori teachers of color by targeting classroom assistants (who are more likely to be people of color) for teacher preparation (DC Montessori Residency, n.d.). These are important first steps in recruiting a more diverse pool of public Montessori teachers, but additional action is needed to attract teachers of color, including targeted recruitment and scholarship funds designated for trainees of color. Further, Montessori trainees and educators need to supplement their Montessori training with training specifically for teaching diverse learners in public Montessori schools. Embedded teacher preparation programs, like the DC Montessori Residency, equip Montessori trainees to work in urban public Montessori schools.

In his keynote address to 4,000 Montessori educators at the American Montessori Society 2016 Annual Conference, noted civil rights attorney Bryan Stevenson stated that "our commitment to education has to be judged not by how we teach the rich but how we teach the poorest members of our society," and he exhorted the Montessori community to "get proximate to families in poverty.... They ought to be getting a Montessori education.... Too many of us are too far away" (2016). The most urgent issue in American public education is to ensure that students living in poverty, many of whom are students of color, receive an outstanding education. Existing research suggests that the Montessori Method has the potential to contribute through schools that respect the developmental needs and cultural backgrounds of all children. Montessori educators can strengthen their work with students of color by limiting enrollment obstacles at their schools and addressing issues of race, culture, and privilege in their classrooms and their communities. Montessori researchers can support teachers' work by disaggregating Montessori student achievement by race and socioeconomic background and informing the Montessori community about what works well and where the community needs to improve. 


\section{AUTHOR INFORMATION}

\section{†Corresponding Author}

Mira C. Debs is a postdoctoral researcher in Education Studies and Political Science at Yale University.

Katie E. Brown† is the DC Regional Coordinator for the National Center for Montessori in the Public

Sector and can be reached at katie.brown@public-montessori.org.

\section{References}

Alston, L. (2008). Why we teach: Learning, laughter, love, and the power to transform lives. New York, NY: Scholastic.

Ansari, A., \& Winsler, A. (2014). Montessori public school pre-K programs and the school readiness of low-income Black and Latino children. Journal of Educational Psychology, 106, 1066-1079. http://dx.doi.org/10.1037/a0036799

Anyon, J. (2014). Radical possibilities: Public policy, urban education, and a new social movement. New York, NY: Routledge.

$\mathrm{Au}, \mathrm{W}$. (2009). Unequal by design: High-stakes testing and the standardization of inequality. New York, NY: Routledge.

Ayer, D. (2016a, May 16). Native Montessori project revived. Montessori Public. Retrieved from http://www.montessoripublic.org/2016/05/native-montessori-project

Ayer, D. (2016b, October 12). Public, private, or something in between? A new model for Montessori schools. Montessori Public. Retrieved from http://www.montessoripublic.org/2016/10/3414/

Banks, K., \& Maixner, R. A. (2016). Social justice education in an urban charter Montessori school. Journal of Montessori Research, 2(1), 1-14. https://doi.org/10.17161/jomr.v2i2.5066

Benson, J., \& Borman, G. (2010). Family, neighborhood, and school settings across seasons: When do socioeconomic context and racial composition matter for the reading achievement growth of young children? Teachers College Record,112, 1338-1390.

Berends, M., \& Penaloza, R. V. (2010). Increasing racial isolation and test score gaps in mathematics: A 30-year perspective. Teachers College Record, 112, 978-1007.

Bowie, L. (2016, February 22). City school board to decide if charter should welcome students who live nearby. Baltimore Sun. Retrieved from http://www.baltimoresun.com/news/maryland/bs-mdmontessori-vote-20160222-story.html

Braddock, J. H., II, \& Gonzalez, A. D. C. (2010). Social isolation and social cohesion: The effects of K-12 neighborhood and school segregation on intergroup orientations. Teachers College Record, 112, 1631-1653.

Brown, K. (2016a, April). Racial diversity in Montessori charter schools. Paper presented at the annual meeting of the American Educational Research Association [AERA], Washington, DC. Available from AERA: http://www.aera.net/Publications/Online-Paper-Repository/AERA-Online-PaperRepository/Owner/952029

Brown, K. (2016b, March). Reading and math achievement for third grade African American students in public Montessori schools. Poster presented at the annual conference of the American Montessori Society [AMS], Chicago, IL. Available from AMS: http://amshq.org/Publications-and-Research/Research-Library/Conference-Handouts

Brown, K. E., \& Steele, A. S. (2015). Racial discipline disproportionality in Montessori and traditional public schools: A comparative study using the relative rate index. Journal of Montessori Research, 1(1), 14-27. https://doi.org/10.17161/jomr.v1i1.4941

Carter, S. C. (2000). No excuses: Lessons from 21 high-performing, high-poverty schools. Washington, DC: Heritage Foundation.

Connor, D. J., \& Ferri, B. A. (2007). The conflict within: Resistance to inclusion and other paradoxes in special education. Disability \& Society, 22(1), 63-77. doi:10.1080/09687590601056717 
Cossentino, J. (2010). Following all the children: Early intervention and Montessori. Montessori Life, 22(4), 38-45.

Danner, N. (2015). Early childhood inclusion in a public Montessori school: Access, participation, and supports (Doctoral dissertation). Available from AMS: https://amshq.org/Publications-andResearch/Research-Library/Dissertations-and-Theses

Danner, N., \& Fowler, S. (2015). Montessori and non-Montessori early childhood teachers' attitudes towards inclusion and access. Journal of Montessori Research, 1(1), 28-41. https://doi.org/10.17161/jomr.v1i1.4944

Darling-Hammond, L. (2010). The flat world and education: How America's commitment to equity will determine our future. New York, NY: Teachers College Press.

DC Montessori Residency. (n.d.). Surround: 15 job-embedded modules packaged into three courses. Retrieved from https://www.dc-montessori-residency.org/ - surround

Debs, M. (2016a, April). Minority parents, Montessori schools: Perceiving cultural fit in theme-based public schools. Paper presented at the annual meeting of the American Educational Research Association, Washington, DC. Available from AERA: http://www.aera.net/Publications/OnlinePaper-Repository/AERA-Online-Paper- Repository/Owner/961581

Debs, M. (2016b). Racial and economic diversity in U.S. public Montessori schools. Journal of Montessori Research, 2(2), 15-34. https://doi.org/10.17161/jomr.v2i2.5848

Diamond, A., \& Lee, K. (2011). Interventions shown to aid executive function development in children 412 years old. Science, 333, 959-964.

Dohrmann, K. R., Nishida, T. K., Gartner, A., Lipsky, D. K., \& Grimm, K. J. (2007). High school outcomes for students in a public Montessori program. Journal of Research in Childhood Education, 22, 205217. doi:10.1080/02568540709594622

Duax, T. (1989). Preliminary report on the educational effectiveness of a Montessori school in the public sector. The NAMTA Journal, 14(2), 55-62.

East Dallas Community Schools. (2010). Summer newsletter 2010 [Newsletter]. Retrieved from the National Center for Montessori in the Public Sector:

http://public-montessori.org/wp-content/uploads/2017/03/2010-EDCS-Outcomes-Charts-andGraphs.pdf

EGUSD staff wants diversity in local charter schools. (2016, March 8). Elk Grove Citizen. Retrieved from http://www.egcitizen.com/articles/2016/03/08/news/doc56df70b6df8db588124584.txt

Ervin, B., Wash, P. D., \& Mecca, M. E. (2010). A 3-year study of self-regulation in Montessori and nonMontessori classrooms. Montessori Life, 22(2), 22-31.

Fabel, L. (2016, October 16). How a Montessori movement is reinventing public schools. One Day Magazine. Retrieved from Teach for America:

https://www.teachforamerica.org/one-day-magazine/how-montessori-movement-reinventingpublic-schools

Fort Peck combines language immersion with Montessori methods. (1998). Tribal College Journal, 9(4), 15.

Furman University, Riley Institute. (2015). South Carolina public Montessori study: Montessori student demographics. Retrieved from https://riley.furman.edu/sites/default/files/docs/MontStudentData12-13.1.20.15.pdf

García, S. B., \& Ortiz, A. A. (2006). Preventing disproportionate representation: Culturally and linguistically responsive prereferral interventions. Teaching Exceptional Children, 38(4), 64-68.

Gay, G. (2010). Culturally responsive teaching: Theory, research, and practice. New York, NY: Teachers College Press.

Gershenson, S., Holt, S. B., \& Papageorge, N. W. (2016). Who believes in me? The effect of student-teacher demographic match on teacher expectations. Economics of Education Review, 52, 209-224. http://dx.doi.org/10.1016/j.econedurev.2016.03.002

Golann, J. W. (2015). The paradox of success at a no-excuses school. Sociology of Education, 88, 103-119. doi:10.1177/0038040714567866 
Goldsmith, P. R. (2010). Learning apart, living apart: How the racial and ethnic segregation of schools and colleges perpetuates residential segregation. Teachers College Record, 112, 1602-1630.

Goodman, J. F. (2013). Charter management organizations and the regulated environment: Is it worth the price? Educational Researcher, 42, 89-96. doi:10.3102/0013189X12470856

Green, T. D. (2005). Promising prevention and early intervention strategies to reduce overrepresentation of African American students in special education. Preventing School Failure, 49(3), 33-41.

Hall, H. R. (2006). Mentoring young men of color: Meeting the needs of African American and Latino students. Lanham, MD: Rowman \& Littlefield Education.

Hall, H. R., \& Murray, A. K. (2011). Intersections between Montessori practices and culturally-based curriculum for African-American students [White paper]. Retrieved from AMS:

https://amshq.org/ /media/Files/Publications-and-Research/Research-Library/Position-and-

White-Papers/White-Papers/Research/Montessori-and-Needs-of-African-AmericanStudents.ashx?la=en

Head Start turns 50. (2015, September 28). The Durango Herald. Retrieved from http://www.durangoherald.com/article/20150928/NEWS01/150929624/SUCAP\%E2\%80\%99sHead-Start-turns-50

Heckman, J. J. (2012). Invest in early childhood development: Reduce deficits, strengthen the economy. Retrieved from The Heckman Equation: http://heckmanequation.org/content/resource/invest-earlychildhood-development-reduce-deficits-strengthen-economy

Hixon, S. (2002). Blending Head Start and Montessori: The best of both worlds. Montessori Life, 14(4), 37-38.

Irvine, J. J. (1991). Black students and school failure: Policies, practices, and prescriptions. New York, NY: Praeger.

Johnson, J. K. (2005, March 9). Preschool utilizes cultural relevancy. Indian Country News. Retrieved from http://indiancountrytodaymedianetwork.com/2005/03/09/preschool-utilizes-cultural-relevancy94582

Johnston, L. J. (2016, October 12). Education self-determination superstars: Cochiti Pueblo takes on language-learning. Indian Country Media Network. Retrieved from https://indiancountrymedianetwork.com/education/native-education/education-selfdetermination-superstars-cochiti-pueblo-takes-on-language-learning/

Kunjufu, J. (2005). Keeping Black boys out of special education. Chicago, IL: African American Images.

Ladson-Billings, G. (1994). The dreamkeepers: Successful teachers of African American children. San Francisco, CA: Jossey Bass.

Ladson-Billings, G. (1995). Toward a theory of culturally relevant pedagogy. American Educational Research Journal, 32, 465-491.

Ladson-Billings, G. (2013). Lack of achievement or loss of opportunity? In P. L. Carter \& K. G. Weiner (Eds.), Closing the opportunity gap: What America must do to give every child an even chance (pp. 11-23). New York, NY: Oxford University Press.

Ladson-Billings, G., \& Tate, W. F., IV (1995). Toward a critical race theory of education. Teachers College Record, 97, 47-68.

Lewis, A. E. (2001). There is no "race" in the schoolyard: Color-blind ideology in an (almost) all-white school. American Education Research Journal, 38, 781-811.

Lewis, C. W., Chambers, T. V., \& Butler, B. R. (2012). Urban education in the 21st century: An overview of selected issues that impact African American student outcomes. In J. L. Moore III \& C. W. Lewis (Eds.), African American students in urban schools: Critical issues and solutions for achievement (pp. 11-30). New York, NY: Peter Lang.

Lillard, A. S. (2005). Montessori: The science behind the genius. New York, NY: Oxford University Press.

Lillard, A. S. (2012). Preschool children's development in classic Montessori, supplemented Montessori, and conventional programs. Journal of School Psychology, 50, 379-401. http://dx.doi.org/10.1016/j.jsp.2012.01.001

Lillard, A. S. (2013). Playful learning and Montessori education. American Journal of Play, 5, 157-186. 
Lillard, A. S., Lerner, M. D., Hopkins, E. J., Dore, R. A., Smith, E. D., \& Palmquist, C. M. (2013). The impact of pretend play on children's development: A review of the evidence. Psychological Bulletin, 139, 1-34. doi:10.1037/a0029321

Lillard, A., \& Else-Quest, N. (2006). Evaluating Montessori education. Science, 313, 1893-1894. doi:10.1126/science.1132362

Lopata, C., Wallace, N. V., \& Finn, K. V. (2005). Comparison of academic achievement between Montessori and traditional education programs. Journal of Research in Childhood Education, 20, 5-13. http://dx.doi.org/10.1080/02568540509594546

Makris, M., \& Brown, E. (in press). A different type of charter school: In prestige charters, a rise in cachet equals a decline in access. Journal of Education Policy.

Mallett, J. D. (2014). Longitudinal academic achievement outcomes: Modeling the growth trajectories of Montessori elementary public school students (Doctoral dissertation). Retrieved from UMI. (2620830)

Mallett, J. D., \& Schroeder, J. L. (2015). Academic achievement outcomes: A comparison of Montessori and non-Montessori public elementary school students. Journal of Elementary Education, 25(1), 39-53. Available from the University of the Punjab: http://pu.edu.pk/images/journal/JEE/PDFFiles/3_v25_no1_15.pdf

McCord, S. (2012, September 19). Santa Cruz City Schools takes public Montessori plan off the table. Santa Cruz Sentinel. Retrieved from http://www.santacruzsentinel.com/general-news/20120919/santa-cruz-city-schools-takes-publicmontessori-plan-off-the-table

Mischel, W., Ayduk, O., Berman, M. G., Casey, B., Gotlib, I. H., Jonides, J. ... Zayas, V. (2011). "Willpower" over the life span: Decomposing self-regulation. Social Cognitive and Affective Neuroscience, 6, 252-256. https://doi.org/10.1093/scan/nsq081

Mischel, W., Shoda, Y., \& Rodriguez, M. I. (1989). Delay of gratification in children. Science, 244, 933938. doi:10.1126/science.2658056

Moll, L. C., Amanti, C., Neff, D., \& Gonzalez, N. (1992). Funds of knowledge for teaching: Using a qualitative approach to connect homes and classrooms. Theory Into Practice, 31(2), 132-141. Retrieved from http://www.jstor.org/stable/1476399

Montessori Accreditation Council for Teacher Education. (2016). Guide to accreditation: April 2016 revision. Retrieved from http://www.macte.org/wp-content/uploads/2016/05/2016-MACTEGuide-to-Accreditation.pdf

Montessori, M. (1976). Education for human development: Understanding Montessori. New York, NY: Schocken.

Moody, M. J., \& Riga, G. (2011). Montessori: Education for life. In L. Howell, C. W. Lewis, \& N. Carter (Eds.), Yes we can! Improving urban schools through innovative education reform (pp. 127-143). Charlotte, NC: Information Age Publishing.

Murray, A., \& Peyton, V. (2008). Public Montessori schools: A delicate balance. Montessori Life, 20(4), 26-30.

National Center for Montessori in the Public Sector. (2014). Growth of public Montessori in the United States: 1975-2014 Retrieved from http://www.public-montessori.org/white-papers/growth-ofpublic-montessori-in-the-united-states-1975-2014/

National Center for Montessori in the Public Sector. (2016a). NCMPS rubric of essential elements of Montessori practice in the public sector. Retrieved from http://www.public-montessori.org/wpcontent/uploads/2016/10/NCMPS-Essential-Elements-4.0.pdf

National Center for Montessori in the Public Sector. (2016b). 2016 Teach Montessori current trainee survey: Summary report. Washington, DC: Author.

Newton, X. A. (2010). End-of-high-school mathematics attainment: How did students get there? Teachers College Record, 112, 1064-1095. 
Noguera, P. A. (2003). Schools, prisons, and social implications of punishment: Rethinking disciplinary practices. Theory Into Practice, 42, 341-350. Retrieved from http://futurescholars.rutgers.edu/FutureScholars/Images/Schools\%20Prisons\%20\&\%20Social\%20 Implications\%20of\%20Punishment.pdf

Nyland, L. (2015). Amendment to the new student assignment plan regarding Leschi Elementary blended model for the 2015-16 school year. School Board Briefing/Proposed Action Report. Seattle, WA: Seattle Public Schools.

Orfield, G., Kucsera, J., \& Siegel-Hawley, G. (2012). E Pluribus... separation: Deepening double segregation for more students. Civil Rights Project/Proyecto Derechos Civiles. Retrieved from https://civilrightsproject.ucla.edu/research/k-12-education/integration-and-diversity/mlknational/e-pluribus...separation-deepening-double-segregation-for-more-students

Paris, D., \& Alim, H. S. (2014). What are we seeking to sustain through culturally sustaining pedagogy? A loving critique forward. Harvard Educational Review, 84, 85-100. http://dx.doi.org/10.17763/haer.84.1.982l873k2ht16m77

Paris, D., \& Winn, M. T. (2014). Humanizing research: Decolonizing qualitative inquiry with youth and communities. Thousand Oaks, CA: SAGE.

Pollock, M. (2008). Everyday antiracism: Getting real about race in school. New York, NY: The New Press.

Prothero, A. (2016, March 8). In charters, using weighted lotteries for diversity hits barriers. Education Week. Retrieved from http://www.edweek.org/ew/articles/2016/03/09/in-charters-using-weightedlotteries-for-diversity.html

Rathunde, K., \& Csikszentmihalyi, M. (2005). The social context of middle school: Teachers, friends, and activities in Montessori and traditional school environments. The Elementary School Journal, 106(1), 59-79. doi:10.1086/496907

Roberts, J. C., \& Fleming, D. J. (2016, January). Mapping the landscape of public Montessori in South Carolina. Paper presented at the annual meeting of the Southern Political Science Association, San Juan, Puerto Rico.

Rodriguez, L., Irby, B. J., Brown, G., Lara-Alecio, R., \& Galloway, M. M. (2005). An analysis of second grade reading achievement related to pre-kindergarten Montessori and transitional bilingual education. National Association of Bilingual Education. In V. González \& J. Tinajero (Eds.), NABE Review of Research and Practice (Vol. 3, pp. 45-65). Mahwah, NJ: Lawrence Erlbaum Associates.

Schonleber, N. (2011). Hawaiian culture-based education and the Montessori approach: Overlapping teaching practices, values, and worldview. Journal of American Indian Education, 50(3), 5-25. http://www.jstor.org/stable/43608610

Shedd, C. (2015). Unequal city: Race, schools, and perceptions of injustice. New York, NY: Russell Sage Foundation.

Skiba, R. J., Michael, R. S., Nardo, A. C., \& Peterson, R. L. (2002). The color of discipline: Sources of racial and gender disproportionality in school punishment. The Urban Review, 34, 317-342. doi:10.1023/A:1021320817372

Stansbury, J. (2012). Dealing with diversity: Administrator, teacher and parent perceptions of the responsiveness of Montessori schools to racial and ethnic diversity (Unpublished master's thesis). DePaul University, Chicago, IL. Retrieved from AMS https://amshq.org/Publications-andResearch/Research-Library/ /media/9E1F8E5CC6E2496E8FE8E183D3BE98BE.ashx

Stevenson, B. (2016, March 12). American injustice: Mercy, humanity, and making a difference. Dr. Nancy McCormick Rambusch Lecture at the annual meeting of the American Montessori Society, Chicago, IL.

Swedien, J. (2013, June 4). Montessori charter school supporters fight back. Leader-Telegram. Retrieved from http://www.leadertelegram.com/News/Front-Page/2013/06/04/Montessori-Charter-Schoolsupporters-fight-back.html

Teach Montessori. (2017). Teach Montessori. Retrieved from http://www.teach-montessori.org/ 
Thernstrom, A., \& Thernstrom, S. (2004). No excuses: Closing the racial gap in learning. New York, NY: Simon \& Schuster.

Thompson, N. L., Franz, D. P., \& Miller, N. C. (2009). Looping: Research summary. Retrieved from https://www.amle.org/BrowsebyTopic/WhatsNew/WNDet/TabId/270/ArtMID/888/ArticleID/311/ Looping.aspx

Tough, P. (2012). How children succeed: Grit, curiosity, and the hidden power of character. New York, NY: Houghton Mifflin Harcourt.

Trondson, E. (2016). Montessori education and social justice: Overlap, potential and areas for growth (Unpublished master's thesis). University of Wisconsin, Madison. Retrieved from https://amshq.org/Publications-and-Research/Research-Library/Dissertations-and-Theses

U.S. Department of Education, National Center for Education Statistics (2013). Table 209.10. Number and percentage distribution of teachers in public and private elementary and secondary schools, by selected teacher characteristics: Selected years, 1987-88 through 2011-12 [Table]. Retrieved from https://nces.ed.gov/programs/digest/d13/tables/dt13_209.10.asp

U.S. Department of Education (2015). A matter of equity: Preschool in America. Retrieved from https://www2.ed.gov/documents/early-learning/matter-equity-preschool-america.pdf

Van Acker, T. (2013). From boutique to big box: A case study concerning teacher change transitioning to a public Montessori school (Doctoral dissertation). Retrieved from ProQuest. (3609604)

Wells, A. S., Holme, J. J., Revilla, A. T., \& Atanda, A. K. (2009). Both sides now: The story of school desegregation's graduates. Berkeley: University of California Press.

Whitescarver, K., \& Cossentino, J. (2008). Montessori and the mainstream: A century of reform on the margins. Teachers College Record, 110, 2571-2600.

Wohlstetter, P. (2016, April). Intentionally diverse charters: Inside schools. Paper presented at the annual meeting of the American Educational Research Association, Washington, DC.

Wong, Q. (2014, June 19). State approval of Montessori school in Salem stalls. Statesman Journal. Retrieved from http://www.statesmanjournal.com/story/news/education/2014/06/19/stateapproval-montessori-school-salem-stalls/11004775/

Yezbick, M. (2007). How Montessori educators in the U.S. address culturally responsive teaching (Unpublished master's thesis). San Francisco State University, San Francisco, CA. Available from AMS: https://amshq.org/Publications-and-Research/Research-Library/Dissertations-and-Theses 